\title{
Interactive Engagement in Rotational Motion via Flipped Classroom and 5E Instructional Model
}

\author{
Jhoanne E. Rafon and Voltaire M. Mistades
}

\begin{abstract}
This study determined the effectiveness of using a flipped classroom approach and the $5 \mathrm{E}$ instructional model in teaching the Physics topic, Rotational Motion. Using mixed methods, this study involved ten Grade 12 students under the Science, Technology, Engineering, and Math (STEM) track. Data showed that the implementation of the four-week study was successful. The students developed a sense of responsibility, participated in the discussion, and followed instructions as a result of the highly positive and highly interactive learning environment. They overcame the challenges that they faced during the learning process such as: the need for guidance / assistance in order to learn, difficulty in coping with the lesson, lack of internet access, incomplete homework, and lack of confidence in taking part in discussion. Most importantly, the students performed very well across a number of formative assessments. The study showed that the students' positive attitude towards learning increased as evidenced by homework completion. In a flipped classroom environment, the students invest in their own learning.
\end{abstract}

Index Terms-Flipped classroom, interactive engagement, rotational motion, $5 \mathrm{E}$ instructional model.

\section{INTRODUCTION}

The educational landscape of the 21 st century is continually changing. New systems and innovations are being introduced to provide the teachers with different strategies that they can use in their field of teaching. As a developing country, the Philippines today needs all kinds of techniques for the growth and development of the students. Just like the changes in modern world, the field of science is expanding and keeps on finding new discoveries. The goal of the science education program is to improve the teaching methodologies or strategies that teachers use. There had been many researches about effective teaching and learning, and the results showed that when good teaching tools and methods are used, effective learning will occur.

The aim of every teacher is to impart knowledge, while the aspiration of every student is to learn as much as possible from the learning-teaching process. In the field of Physics, this is a bit difficult to realize as the students find Physics concepts complex and difficult to understand. This may be due to the use of mathematics as its language which requires skills in computation. Misunderstandings and misconceptions among students arise when Physics

Manuscript received March 24, 2020; revised October 16, 2020.

J. E. Rafon is with the Centro Escolar University, Manila, Philippines (e-mail: jhoanne_rafon@dlsu.edu.ph).

V. M. Mistades is with the Science Education Department of the Br.Andrew Gonzalez FSC College of Education, De La Salle University, 2401 Taft Avenue, Manila, 0922, Philippines (e-mail: voltaire.mistades@dlsu.edu.ph). concepts are not properly explained [1].

Physics is a science subject that students often find very difficult and this is the reason why students have low achievement in the subject. According to Aina [2], students usually perform very poorly in physics in all levels of education. Poor achievement in physics could be attributed to many factors ranging from the attitude of students towards the subject, methods of teaching the subject, lack of motivation on the part of the teachers, lack of basic sciences background at the primary school, and the strategies used by the teacher. This implies that the mastery of physics concepts might not be fully achieved without the use of instructional resources [3].

Another reason identified is that the teaching method used may not be interesting, thereby resulting to low academic performance in Physics. Ibanez [4] notes that the teacher should know how to teach physics in a manner that will catch the students' attention and motivate them to learn the course. So, how can we improve the instructional approach of Physics Education? What approach will help the students to deepen their understanding of the concepts?

In this regard, the researchers thought of an approach that will address the problem. An interactive engagement approach with the use of Flipped Classroom and 5E Instructional Model could help the students to deepen their understanding of the concepts. To address the complexity of Physics, the classroom approach will utilize a variety of teaching techniques to develop and enhance the abilities, interests and attitudes of the learners.

\section{REVIEW OF RELATED LITERATURE}

\section{A. Flipped Classroom}

The Flipped Classroom is a learner-centered teaching and learning method in which the traditional classroom model is reversed [5]. In traditional lecture format, students spend majority of contact hours listening to lectures, but with flipped classroom, the instruction and preparation are done before class at home and classroom contact hours are filled with interactive and collaborative learning opportunities. The purpose of flipping a class is that students watch these video recordings before coming to class, freeing up class time for troubleshooting difficult concepts, answering student questions, engaging students in active learning, and creating connections to everyday life. Instructors will find that their role has shifted from what has been called the "sage on the stage" to more of the "guide on the side" and students" engagement with the material has come to the forefront [6].

In the recent research conducted by Limueco and Prudente 
[7], the students have expressed positive feedback on the utilization of technology and the provision of various activities in the classroom, after going through the intervention. Results of their study revealed that Flipped Classroom approach yielded a positive impact on the students' understanding.

\section{B. 5E Instructional Model}

The 5E Instructional Model, which is based on the constructivist learning approach, states that students learn best by trying to make sense of something on their own with the teacher as a guide to help them along the way. The $5 \mathrm{E}$ Instructional Model encourages students' active participation in the teaching learning process and consists of five distinct phases; 1) engagement, 2) exploration, 3) explanation, 4) elaboration and 5) evaluation. The approach is very much student-centered and is more about discovery and deeper understanding than direct instruction. At the engagement phase of the model, students' preconceptions are uncovered. The activities during this phase make connections to past experiences and expose students' misconceptions. In the following phase, exploration, students are given time to think, plan, investigate, and organize collected information. This phase should be concrete and hands on. The teacher provides the students with time and opportunity to investigate on their own. In the explanation phase, the teacher helps students focus their attention on their previous engagement and exploration experiences by providing opportunities to explain their understanding. In the fourth phase, elaboration, students are given the opportunity to expand and solidify their understanding of the concept by applying it to a real-world situation. This phase facilitates the transfer of concepts to closely related new situations. Finally, in the evaluation phase, the learners are encouraged to assess their own understanding and evaluate their progress in achieving the learning objectives [8], [9].

\section{Interactive Engagement}

According to Hake [10], Interactive Engagement (IE) methods are those designed to promote conceptual understanding through interactive engagement of students in heads-on (always) and hands-on (usually) activities which yield immediate feedback through discussion with peers and/or instructors. Interactive Engagement uses teaching techniques such as peer instruction or peer tutoring, active learning problem sets, demonstration and constructivist classroom dialogue.

Georgiou and Sharma [11] put forward the idea that "Active learning is the increasing of student participation, or 'interactivity', for the purpose of positively affecting student learning and attitudes". This is similar to what John Dewey believed that "people can learn by participating in relevant learning experiences" [12]. Thus, when the students are actively engaged, there is greater chance of grasping the lesson. The recent study [13] that looked at how to most effectively integrate digital technology into educational setting revealed a consensus that particular strategies can promote significant improvement in student learning.

\section{Problem Statement}

This research aimed to determine the effectiveness of teaching Rotational Motion through Interactive Engagement in a Flipped Classroom and 5E Instructional Model. The research aimed to answer the following problems:

1) How did the students' understanding develop as they go through the lesson in the $5 \mathrm{E}$ Instructional Model in each of the phases?

2) How was interactive engagement manifested in a flipped classroom and 5E Instructional model in terms of:

- active participation;

- learning environment and;

- formative assessment

\section{METHODS}

This study utilized qualitative research design. A public school in the Division of Rizal, Philippines was the setting of the study. All the ten students in one intact class of Grade 12 STEM students were purposively selected as the participants of this study. One of the researchers served as the teacher of the class. The implementation process took place over a 4-week period, with 2 to 3 lessons per week. The topics covered are translational and rotational motion, rotational kinetic energy, moment of inertia and torque. For each session, the Flipped Classroom component consisted of the students watching one to three videos, all of which do not exceed ten minutes, viewing presentations and/or answering homework. All learning materials were available online through Edmodo or given to students. To determine if the students sufficiently prepared for the class, homework notes were checked. In the face-to-face session, the students were exposed to variety of engaging activities such as think-pair-share, collaborative work, simulations, and word problems and inquiry-based learning. Quizzes and other assessments were also included during the in-class sessions. After four weeks (12 in-class sessions), interviews were conducted with the students.

\section{DAta Collection AND ANALysis}

The survey questionnaire, interview questions and reflective logs were adapted from the work of Camel [14]. To determine students' understanding as they go through the lesson in the 5E Instructional Model and how interactive engagement in a Flipped Classroom and 5E Instructional Model was manifested in terms of active participation, learning environment and formative assessment, the students were interviewed after the intervention. A video camera was used to document the entire class session and the interviews. The data obtained through interviews, documents, survey questionnaire, reflective logs, and other materials were thematically coded for qualitative data analysis.

\section{RESUlTS AND DISCUSSION}

A. How did the Students' Understanding Develop As They Go through the Lesson in 5 E Instructional Model? 
The 5E instructional model can provide Physics teachers with a holistic framework of flipped classroom design. Through the use of this model, all the activities of Physics flipped classroom can be categorized into one of the five instructional phases.

Fig. 1 shows a graphical representation of the 5E flipped classroom instructional model. The engagement, exploration, explanation, and evaluation phases occur outside the classroom. The main focus of in-class learning is the elaboration and evaluation phase. The engagement phase is still necessary inside the classroom.

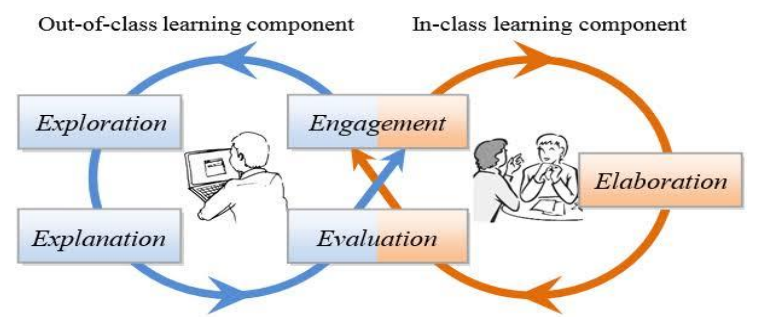

Fig. 1. 5E flipped classroom instructional model [15].

Table I shows that the engagement and evaluation phase were performed both outside and inside the classroom.

\begin{tabular}{|c|c|c|}
\hline Phase & $\begin{array}{c}\text { Out-of-class Learning } \\
\text { (at home) }\end{array}$ & $\begin{array}{c}\text { In-class Learning } \\
\text { (at school) }\end{array}$ \\
\hline Engage & $\begin{array}{l}\text { Teacher used video } \\
\text { lecture, readings and } \\
\text { writing homework to } \\
\text { engage students }\end{array}$ & $\begin{array}{l}\text { Teacher engage the } \\
\text { students by quick recall } \\
\text { (brief review) students' } \\
\text { out-of-class } \\
\text { Students do graphic } \\
\text { organizer, picture or } \\
\text { video clip analysis }\end{array}$ \\
\hline Explore & $\begin{array}{l}\text { Students writing } \\
\text { homework and explored } \\
\text { online resources }\end{array}$ & $\begin{array}{l}\text { Students explore through } \\
\text { interactive simulation, } \\
\text { video review, and gallery } \\
\text { walk }\end{array}$ \\
\hline Explain & $\begin{array}{l}\text { Teacher introduced the } \\
\text { learning materials }\end{array}$ & $\begin{array}{l}\text { Students explain what } \\
\text { they have learned } \\
\text { through small group } \\
\text { discussion and } \\
\text { think-pair-share }\end{array}$ \\
\hline Elaborate & $\begin{array}{l}\text { Teacher offered } \\
\text { one-on-one meeting or } \\
\text { talk session }\end{array}$ & $\begin{array}{l}\text { The teacher discussed the } \\
\text { topic and corrected their } \\
\text { misconceptions through } \\
\text { further argument and } \\
\text { explanation. They do } \\
\text { group work or activities } \\
\text { such as problem solving } \\
\text { and reporting for deeper } \\
\text { understanding. Students } \\
\text { group work or activities } \\
\text { presentation, class } \\
\text { discussion }\end{array}$ \\
\hline Evaluate & $\begin{array}{l}\text { Teacher check online } \\
\text { homework and provided } \\
\text { feedback on students' } \\
\text { outputs }\end{array}$ & $\begin{array}{l}\text { Students make daily life } \\
\text { example, journal } \\
\text { reflection, word } \\
\text { problem, quizzes and } \\
\text { homework as formative } \\
\text { assessment }\end{array}$ \\
\hline
\end{tabular}

In the Engage phase of the 5E Instructional Model, the students took part in flipped classroom. Students' prior knowledge was assessed using simple but meaningful tasks. The face-to-face component of the engage activities include graphic organizer, quick recall, picture or video clip analysis.
Student U-1 enjoyed the engage phase, it motivated her to actively participate in the activities.

"I enjoyed doing and participating in the activities because through engaging lessons they are giving an impact." - Student $U-1$

When the teacher asked in the interview, "Is the video helpful? Are you learning effectively?" Student M-4 explained the advantage of watching video lessons outside the classroom:

"Yes, ...because it was easy for us to understand the lesson because of the video we watched already and in class." - Student M-4

Video lessons provided them a chance to learn at their own pace and understand it before the classroom session. While the students were analyzing pictures and videos, they were able to relate the different ideas about the lesson that they are going to study and learn.

The explore phase of 5E involved differentiated learning instruction such as interactive simulation, video review, and gallery walk. During this phase, recent concepts and potential skills were identified, since after the knowledge is assimilated, it is accommodated. The students have accommodated new knowledge or additional information about rotational motion. As one student commented:

"I enjoyed being happy to explore something we doesn't know find a new one who helps a lot in the form of studying."

When the students were asked, "did you follow a process carefully in order to be successful?" one student answered, "The time when we need to answer all the questions posted in the room. We answered the questions by using a one-by-one or step-by-step procedure".

Even though the Gallery Walk activity was difficult as observed by the teacher, one student commented

"I enjoyed searching and looking for answers"

During explore phase, the students are happily exploring the PhET Simulation and looking for answers.

In the Explanation phase of 5E, the teacher helped the students focus their attention on their previous engagement and exploration experiences by providing opportunities to explain their understanding. The students corrected their misconception and constructed deeper understanding as they explained the concepts. There is also a part in which they explained what they have learned through small group discussion and think-pair- share.

The students were given a problem set and concept that they needed to explain in front of the class. During Think-Pair-Share, they are working seriously and arguing about the topic given. The teacher is happily observing them because most of the student lack confidence in their answer but are willing to learn, so they have no choice but to cooperate and collaborate with their partner. Two students commented:

"...in our class before we explain we really know or studying our report before explain it in the class."

"...how those topics come to mind and how I cope up on those lessons." 
There was an observable improvement on the students and positive teacher's interaction. As two students responded:

“... lessons are becoming clearer and questions in my head are getting its answer"

"I enjoyed how the teacher find way (every topic) easily."

After the students underwent the first three phases, the teacher reviewed points in the video and activities which were not clear to the students. The students do group work or activities such as problem solving and reporting for deeper understanding. The teacher encouraged them to present their solutions on the board and explain how they obtained the answer,

"I enjoyed the discussion of our teacher, because she's clearing up things that is blur to us."

"One of the problems that I have encountered was computing for translation and rotational motion. For me, it is a bit confusing. To resolve it, I re-watched the video clip given to us and ask some of my classmate to discuss it with me and it worked.

Students' understanding developed in the Evaluate phase through the daily life example about the things that the students do every day as part of their normal life that can be connected to specific concept in the lesson. Despite the challenges they have encountered during problem solving, they have successful experiences during group work and activities. It was evident when three students responded:

“... when there's a complex topic about problem solving; it's such a good feeling to finish those activities and answering their problem."

"...when we do a group activity about rotational and translational variables including its equation. It is a fun experience and it also helped us share our ideas with one another."

The students were given a set of questions or exercises evaluating their skill or knowledge in a certain topic discussed. It was evident that learning and participation were present throughout the session. As a student commented, "This will test if our answers or what we have learned is fully correct or not."

The aim of Evaluation phase is to determine if students understood the scientific concepts that connect to old and new experiences about rotational motion, such activities include daily life example, journal reflection, word problem, quizzes and homework.

\section{B. How Was Interactive Engagement Manifested in a Flipped Classroom and 5E Instructional Model?}

The results presented here are based on teacher observation of the class and answers during the interview. From the data, indicators were identified and categorized. Since the teacher was provided with only teacher- camera videos, no episodes of student individual work (that is students working alone) were included in the analysis. The researchers used an adapted Learner Engagement Rubric and modified as shown in the diagram below:

1) Active participation empowers individuals in the activities and relationships of everyday life leading to them living as independently as possible. In this manner, students are active in participation if they remain on-task during the whole duration of class. According to a student,

"In our class, we always do group activities, watching videos clips and discussion."

The students are maintaining their concentration during the session as one student said, “I am a student who's always listening to my teacher and also completing my homework." ... "ask and ask until we got the answer."

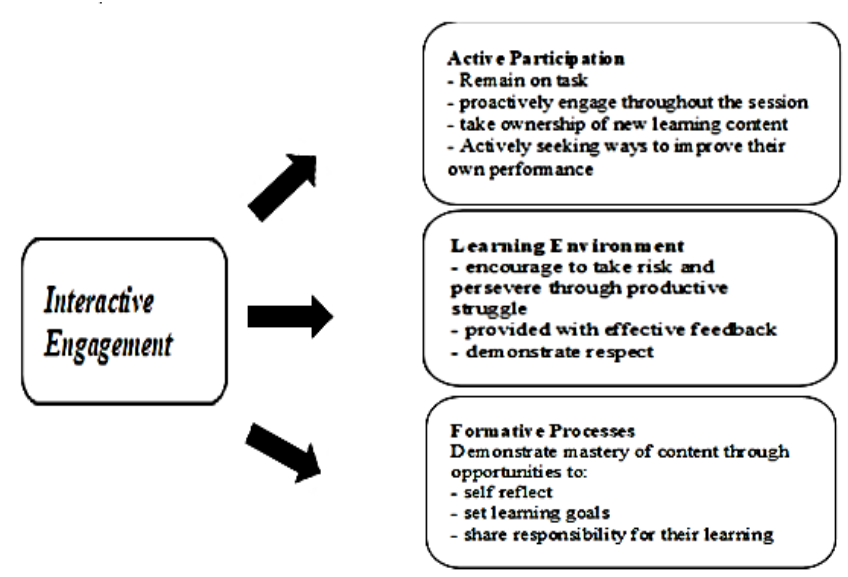

Fig. 2. Indicators of learners engagement (International Center of Leadership in Education [16]).

The students are proactively engaged throughout the session as they strengthen their relationship with their classmates.

During group activities students are sharing their ideas and arguing with each other in a good manner. A student recalled,

"Our day in FC and 5E IM is fun and knowledgeable! Sharing of ideas, the groupings and also the reporting." Other students' added, "...each of us became active in every activity we have." And "I am not fond of sharing ideas but with it, it helps me to cope up."

The students are said to be active participant when they take ownership of learning content. They are accountable and responsible for executing particular task. As stated by the student, "I did my role and the feeling is so happy and enjoyed."

Lastly, active students are seeking ways to improve their own performance. These are the students who, even though they are struggling, they seek ways to improve and enhance their performance and learn effectively. As three students responded:

"I am trying my best to also participate."

"I just adjust in that type of teaching and it's fun to do and its make myself more active in class."

"I resolve it by messaging my teacher and tell my friend on how to resolve then problems"

2) Learning environment is the physical setting where teaching and learning occur, and where procedures and routines adapt to the learning task needed. Students face challenges and struggles but those who take risks and persevere through productive struggle learn more.

During the topic about rotational motion, which is quite complicated and difficult, at first, they are adjusting and uncertain with their answers. As one student commented, "the topics given are hard to understand when I'm alone and 
will going to analyze."

Learning is active when students are provided with effective feedback to guide them in their learning. According to a student, if a homework is written, it is either returned only when the quarter is about to end, or it is not returned at all. He also added that, "Buti nalang po ma'am dinidiscuss natin yung homework kasi yung iba po check lang po basta. Tapos na. (It's a good idea, ma'am that you discussed our homework unlike others who just checked it, then it's done)", there were only few teachers who discuss homework items in class. Many do not practice this habit because they just continue discussing the next topic since the time is not enough to finish the content of the curriculum guide.

Lastly, learning environment is conducive and peaceful if the students know how to respect teachers, peers and learning environment.

The seating arrangement became an advantage for the students to change pair and groupmates during activities that will support the opinion and idea of one another. It is not just about cleanliness and orderliness of the room, beautiful decorations and complete materials but mostly it is about the person inside the classroom that matters. If the student is respectful, all of it will put into place.

As a student stated, "Be responsible enough and give full attention so that I will be able to understand the entire given topic." Even though they have difficulty in coping up, the student responded "... all I can do is just to follow what does the teacher instruction so that I can easily manage my time in every subject."

3) Formative processes are divided into three indicators a) self-reflect, b) set learning goals, and c) share responsibility for their learning. For additional assessment, quizzes, homework and activities are utilized The research also used reflective logs, survey and interview questions to assess the expected outcomes.

As the teacher interviewed the students the responses made her happy. The students reflected on their learning as they responded:

"My learning is more effective not just on having knowledge but in terms of by being responsible and conscious in my time."

"I am becoming more responsible and time manageable."

The students developed a sense of responsibility and learned to manage time compare before that they are incomplete in homework, lack of self-confidence and left out of class.

On the other hand, the students reflect also in their lives. As the teacher read the interview, the students are now aware about their education and life. They connect the lesson and experiences in real life situation. As the students commented:

"One mistake can take everything away."

"In every step I know it's a decision for me and I need to trust on that answer and be independent on answering it."

"I said to myself na kailangan magtapos ng pag-aaral to be successful." ("I said to myself, I need to successfully finish my studies.")

The students learned to share responsibility for their learning. They are now sharing ideas, collaborate, participate and became responsible in their own learning. During activities, one student commented, "Everyone did contribute to come up with a correct answer every now and then."

The students learned to set learning goals. Before, they struggle in answering their homework and managing their time, but after the intervention, they said that "....do the entire given task in a short span of time." because "...we need to manage our time at it sense, it helps us to be responsible". Added to, "...must finish it at home so can get along to the class in during discussion."

From the teacher's perspective, the students are now ready to face their college life. As a student responded, "I see it as a very useful in my future not just because of what I have learned on the topics but on how I manage my time in the near future."

The formative assessment demonstrates the mastery of content, feasibility of the intervention and monitor student learning.

\section{CONCLUSION}

The implementation of study was successful and interactive. The students developed a sense of responsibility and a commitment to actively take part in the discussion. They overcame the challenges that they faced during the learning process such as: the need for guidance / assistance in order to learn, difficulty in coping with the lesson, lack of internet access, incomplete homework, and lack of confidence in taking part in discussion. At the end of the study, positive effects were highlighted which made learning enjoyable and fun, by building confidence and by espousing an active, independent, and collaborative learning atmosphere. The students' positive attitude towards learning increased homework completion and resulted in the students investing in their own learning.

The pedagogical implications of the results of the study include:

1) The continuous use of flipped classroom and $5 \mathrm{E}$ instructional model because these can highly develop and improve the critical skills of the learners

2) the use of teaching strategies that focus on all areas that affect the student's performance, in particular fostering inquiry skills and all facets of understanding.

3) a well-planned student-centered learning process that encourages students to: make inferences, construct highlevel questions, make critical observations, and be conscientious and involved in the decision-making process.

To determine the appropriateness and suitability of the model in other subject areas and grade levels, further research is needed. Among others, future studies would have to consider exploring the most effective technologies for recording and storing the lectures as well as evaluating and assessing mastery learning as a separate or a supplementary component to the model.

\section{CONFLICT OF INTEREST}

The authors declare no conflict of interest

ETHiCAL Clearance 
The study was approved by the institution.

\section{AUTHOR CONTRIBUTIONS}

This manuscript is based on the Master's degree thesis research conducted by Jhoanne Rafon under the supervision of Voltaire Mistades. The preparation of the manuscript for submission to IJIET was done collaboratively by both authors; both authors approved the final version.

\section{ACKNOWLEDGMENT}

The authors would like to acknowledge the Science Education Department, Br. Andrew Gonzalez FSC College of Education for all the support.

\section{REFERENCES}

[1] D. J. Naval, "Development and validation of tenth grade physics modules based on selected least mastered competencies," International Journal of Education and Research, pp. 145-152, 2014.

[2] K. J. Aina, "Instructional materials and improvisation in physics class: Implications for teaching and learning," IOSR Journal of Research \& Method in Education (IOSR-JRME), pp. 38-42, 2013.

[3] D. C. Omebe, "Effect of instructional resources on student's achievement in physics and chemistry in secondary schools in ebonyi state, Nigeria," European Journal of Training and Development Studies, pp. 56-65, 2015.

[4] G. O. Ibanez, "Development and acceptability of competency- based learning activities in teaching world literature," International Center of Leader in Education, 2015.

[5] H.-S. Sohng, "Effects of project-based flipped classroom on the affective attitude and metacognitive learning strategies of preservice teachers of English," English Language and Literature, vol. 22, no. 2, pp. 167-192, 2016.

[6] E. C.-H. Seong, "A case study of the flipped classroom in a Korean University general English course," Journal of Pan-Pacific Association of Applied Linguistics, pp. 71-93, 2016.

[7] J. Limueco and M. Prudente, "Flipping classroom to improve physics teaching," Advance Science Letters, vol. 24, no. 11, pp. 8292-8296, 2018.

[8] R. W. Bybee et al., The BSCS 5E Instructional Model: Origins, Effectiveness, and Applications, Colorado Springs: BSCS, 2006.

[9] E. Taşlidere, "A study investigating the effect of treatment developed by integrating the $5 \mathrm{E}$ and simulation on pre-service science teachers' achievement in photoelectric effect," Eurasia Journal of Mathematics, Science \& Technology Education, pp. 1-16, 2015.

[10] R. R. Hake, "Interactive engagements versus traditional methods: A six-thousand-student survey of mechanics test data for introductory physics course," American Journal of Physics Teachers, vol. 66, no. 1, pp. 64-74, 1998.

[11] H. Georgiou and M. D. Sharma, "Does using active learning in thermodynamics lectures improve students' conceptual understanding and learning experiences?" European Journal of Physics, vol. 36, pp. 1-13, 2015.

[12] D. Mike. (2018). Positive encourager. [Online]. Available: https://www.thepositiveencourager.global/john-deweys-approach

[13] M. N. I. Sarker et al., "Leveraging digital technology for better learning and education: A systematic literature review," International Journal of Information and Education Technology, vol. 9, no. 7, pp. 453-461, 2019.

[14] C. Camel. (2011). An evaluation of the flipped classroom. [Online]. Available: https://camelportfolio.files.wordpress.com/2012/03/ camel-c-final-epd- for-the-flipped-classroom.pdf

[15] C. K. Lo, "Toward a flipped classroom instructional model for history education: A call toward a flipped classroom instructional model for history education : A call for research," 2017.

[16] International Center of Leadership in Education. [Online]. Available: https://leadered.com/wp-content/uploads/RRErubrics.pdf

Copyright (C) 2020 by the authors. This is an open access article distributed under the Creative Commons Attribution License which permits unrestricted use, distribution, and reproduction in any medium, provided the original work is properly cited (CC BY 4.0).

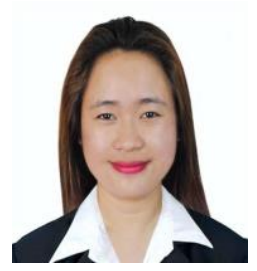

Jhoanne E. Rafon is a former Public Secondary School Teacher in Tanay, Rizal, Philippines. She received her bachelor's degree in secondary education major in physical sciences from University of Rizal System, Morong Campus, Morong Rizal, Philippines, in 2015; her master's degree in science teaching major in physics from De La Salle University, Manila, Philippines in 2019. She is currently a doctoral degree student in science education major in physics, also at De La Salle University. Her current research includes problem solving in physics and pedagogical techniques in teaching physics.

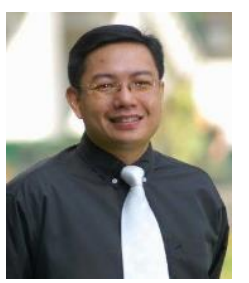

Voltaire M. Mistades was born in Manila in June 1972. He earned the Ph.D. in science education from De La Salle University, Manila, Philippines in 2011. $\mathrm{He}$ is currently an associate professor of the $\mathrm{Br}$. Andrew Gonzalez FSC College of Education at the De La Salle University, Manila, Philippines. His research interests include physics education, values education, and learning and teaching in higher education. Dr. Mistades is a member of the Samahang Pisika ng Pilipinas (Physics Society of the Philippines). 